\section{The Bulletin Analytique}

'The Bulletin Analytique is a journal of abstracts, issued by the French Government's new Service de Documentation (see p. 947). The director of the Service is Prof. P. Auger, and the chief editor of the Bulletin is Dr. N. Thon. The Bulletin was to have been issued in fortnightly parts. The first six parts, for January-March of this year, have been published in one fascicule. Nos. 7-8 appeared in April and No. 9 is dated May. The size of the page is about $6 \frac{1}{4}$ in. $\times 9 \frac{1}{2}$ in. It is hoped that a complete annual volume will contain about one thousand pages. The abstracts are classified under eighteen subjects, which are : mathematical physics ; corpuscular physics; structure of solids and liquids; mechanics and heat; radiation and optics; electricity and magnetism ; astrophysics and geophysics ; thermodynamics and chemical statics and dynamics; electrochemistry, photochemistry, radio chemistry, and photography ; colloids and adsorption; chemistry of minerals, mineralogical chemistry and geochemistry; organic chemistry; metallurgy; industrial chemistry and materials; agricultural chemistry; biological chemistry; agriculture ; physiology. The titles of all papers and all abstracts are given in French, with the name of the author, the place where the research has been done, the journal in which it has appeared and the language of the original. Abstracts of unpublished papers in the Service's archives are given a special mark.

\section{Emile Duclaux}

Prof. Pierre Emire Duclaux, the well-known chemist and bacteriologist, was born at Aurillac, capital of the Cantal Departement of France, on June 24, 1840. In 1857 he went to Paris, where he was educated at the Lycée Saint Louis. Two years later he passed the entrance examination not only at the Ecole Polytechnique but also at the Ecole Normale Supérieure, where Pasteur, with whom he became closely associated, was sub-director of scientific studies. In 1862 he became an agrégé and assisted Pasteur in his investigation of the disease of silkworms which was then prevalent in several departments of France. In 1865 he was appointed professor of chemistry at Tours, from which he was transferred in a similar capacity to Clermont-Ferrand, where he had about a hundred pupils, most of whom were medical students, including Emile Roux, his successor at the Pasteur Institute. From Clermont-Ferrand he went to Lyons, where he remained five years as professor of physics. Finally he settled in Paris in 1878 as professor of physics and meteorology in the Agronomic Institute.

In 1886, Duclaux was appointed professor of biological chemistry at the Sorbonne and held this position until his death. In 1888 he was elected a member of the Academy of Sciences in the section of rural economy, and in 1894 he became a member of the Academy of Medicine. In 1895 he was appointed Pasteur's successor in the Institute in the Rue Dutot. In the words of Prof. H. Roger, "Duclaux possessed all the essential qualities of a professor-erudition, critical sense, a lucid style and a taste for polemics". $\mathrm{He}$ was a remarkably prolific writer. In addition to more than eighty articles dealing with molecular physics, chemistry, meteorology, enzymes, physiology of digestion, vegetable physiology, bacteriology, etc., he was the author of a number of books, including "Ferments et maladies" (1882), "Le Microbe et la maladie" (1885), "Pasteur, Histoire d'un esprit" (1896), which was translated into English in 1920, "Traité de Microbiologie" (1898-1901) and "L'hygiène sociale" (1902). He was also founder in 1887 of Annales de l'Institut Pasteur. He died on May 3, 1904.

\section{Huxley's Teaching at Edinburgh}

During the four years when the Challenger was sailing the oceans of the world, Sir Wyville Thomson left his natural history class-room in the University of Edinburgh to lead the expedition. The vacancy was filled temporarily by two naturalists of European fame-Julius Victor Carus, of Leipzig, who conducted the zoology courses in the summer sessions of 1873 and 1874, and Thomas Henry Huxley in 1875 and 1876. An account of their tenure of the natural history chair, by Prof. James Ritchie, appears in the summer number of the University of Edinburgh Journal (pp. 206-212), the information about Huxley being gathered mainly from the class roll-books, and from a small notebook of Huxley's dealing with "Lectures, Edinboro", in the Huxley Library of the Imperial College of Science and Technology. Huxley drew a crowded audience for his introductory lecture on "The Crocodile"-it was a free lecture-and he laments that many parsons were present who "came to curse and didn't remain to pay". His course proper, covering twelve weeks, traversed the whole animal kingdom from Protozoa to Mammalia, and was predominantly morphological and classificatory, although generally some reference was made to development and to the fossil record of a group.

It was a heavy programme, and Huxley as well as the students felt the rush and strain. Joseph Thomson, student in 1876, who became one of the greatest of the geographical pioneers in Africa, wrote, "Huxley's usual lectures are something awful to listen to . . to master his language is something dreadful", and yet "I would not miss them ... . they are something glorious, sublime". Huxley's own impression of the course was equally definite. "I . . . positively polished off the Animal Kingdom in fiftyfour lectures. French without a master in twelve lessons is nothing to this feat." The class roll-books show that a practical class in zoology was first held in 1872 under Wyville Thomson, but except for a short record in the University Calendar there is no record of the scope of the work of the earliest practical classes. Huxley's notebook indicates that the class, conducted by the assistant under the professor's supervision, examined fourteen different types, and Prof. Ritchie points out the curious fact that the practical class appears to have traversed the animal kingdom from Vertebrates to Infusoria almost in the reverse order from that adopted in the lectures. 